\title{
LEGAL AND ACCOUNTING SUPPORT FOR OPERATIONS WITH CRYPTOCURRENCY IN THE CONDITIONS OF INNOVATIVE APPROACHES TO DOING BUSINESS
}

\section{Ovsyuk N. V.}

\section{INTRODUCTION}

Currently in terms of continual technological progress, significant development of IT technology, the world is increasingly made payments using electronic money. Also there is a noticeable spread in the use cryptocurrency as a completely new, innovative payment instrument of XXI century. Today the financial systems of individual countries, as well as other components of the economy are improving and progressing in the context of globalization and the total computerization. This contributes to the emergence of new financial institutions, instruments and forms of interaction between businesses.

Dollar over the past 100 years has lost more than $95 \%$ of its value, this fact may eventually force investors to buy bitcoins that for 9 years since the establishment showed strengthening at 8.5 million percent. Bitcoin was estimated at 0.07 dollars August 16, 2010 and now it reaches the mark of 8000 dollars. No other currency or asset did not generate a similar revenue for the same period ${ }^{1}$.

Current conditions of market economy in Ukraine and its participation in world globalization necessitate are strengthening the monetary system, improving the efficiency of monetary policy in order to strengthen their influence on structure of adjustment and further development of the economy. That is why the functioning and accounting software transactions related to cryptocurrency is relevant and requires further research, especially in the absence of a legal definition in Ukraine.

Among scientists, in the works of which were investigated cryptocurrency concept, its essence and importance in innovative forms of business distinguished: A.V. Baginsky, S.V. Vasilchak, M.V. KunitskyIlyash, M.P. Dubina, A.S. Goncharenko and others. Such foreign scientists

\footnotetext{
1 Obozrevatel / Ринки та компанії, 16 травня 2019 p. URL: https://www.obozrevatel.com/ukr/ economics/economy/kurs-dolara-vpav-na-95-analitiki-ozvuchili-nespodivanij-prognoz.htm
} 
as C. Reiborn, M. Sivitanides, C. Graydon and others paid attention to consideration on accounting transactions with cryptocurrency.

However a number of global, geopolitical, national, regional crises, the negative effects of globalization encourage individuals and businessmen to seek alternative means of storing and increase of money. Ukrainian modern consumer especially dire need speed, security, settlements, absence of third-party, independent currency values on the political situation in the country and cryptocurrency meet those needs. Users in Ukraine in the use of cryptocurrency increasingly recognize their performance that needs improvement to ensure these areas of financial instruments.

Cryptocurrency (digital currency) acts as a decentralized digital measurement of value business processes that can be expressed in a digital form and function as a medium of exchange, store of value or unit of account, based on mathematical calculations is their result and has encryption protection of account.

Cryptocurrency - "virtual money". It should be noted that for the production, regulation and checking transfers use encryption encoding.

\section{Peculiarities of Identification and Determination of the Legal Status of Cryptocurrency}

Virtual currency has similarities with electronic money, but we must understand that these are two different concepts. Electronic money - the unit value stored on the electronic device is accepted as means of payment by other persons than the person who produces it, is the monetary obligations of the persons which is executed in cash or by bank transfer. Electronic money unlike cryptocurrency have legal status, legally defined issuer fixed the offer and made over them regulation and supervision. Digital currency, in turn, hasn't legally defined the issuer and is produced by Mining (solving difficult mathematical problems with getting a reward virtual coins), the legal status is uncertain in many states, moreover, its use carries many risks. Cryptocurrency has a number of advantages and disadvantages. The former include the following:

1. Decentralization. Cryptocurrency an independent currency. Its emissions nobody regulates or control the movement of funds.

2. Ability to self-issue (mining) cryptocurrency. It can get by exercise computational operations using its own or leased specialized equipment. 
3. Anonymity transactions. Since the creation of electronic purses cryptocurrency don't require personal data and all calculations in this system are confidential, the information about the participants of transactions cannot find any other users or public authorities. But at the same time, this advantage is a disadvantage, since absence of personal data creates favorable conditions for the transfer of funds between criminal organizations. Also in case of loss of access to electronic wallet, the user can no longer turn back the funds that it kept.

4. Lack of inflation. For the most systems of cryptocurrency limit of virtual coins is limited, so inflation to this currency is not threatened.

5. Reducing the time of payment. If the payment is reduced to pressing instead of relying on the introduction of various payment information such as the card number, the time spent taxpayer is significantly reduced. In addition, the risk of fraud may be lower because the card number or the account number is not required to disclose to the recipient. ${ }^{2}$

There are many shortcomings that hinder the implementation cryptocurrency as payment. The main are the following:

1. Significant fluctuations (Fig. 1).

As you can see, in the early 2017 Bitcoin exchange rate against the dollar was less than $\$ 1,000$, from the moment it began a significant increase in December 2017 and reached a peak for the entire period of its existence - about $\$ 17226$. Then there is depreciation. On 10.04.2018, it stood at $\$ 6877.21$ for 1 Bitcoin.

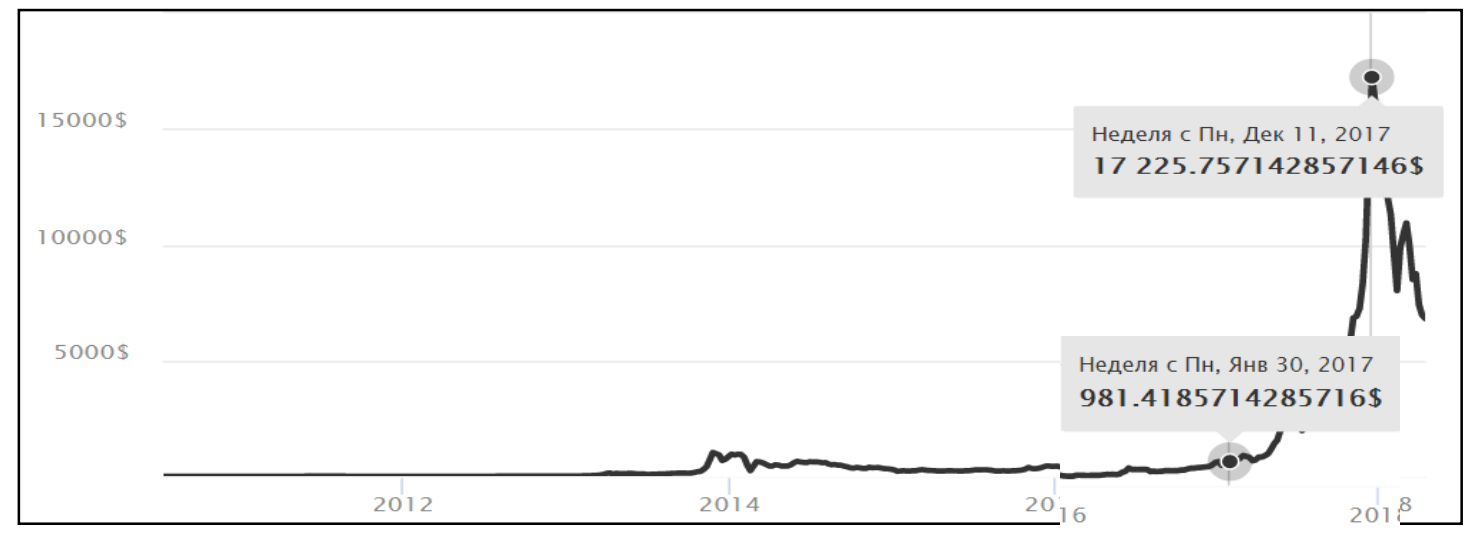

\section{Fig. 1. Bitcoin course against the dollar ${ }^{3}$}

${ }^{2}$ Васильчак С.В., Куницька-Іляш М.В., Дубина М.П. Використання криптовалют в сучасних економічних системах України: перспективи та ризики. Науковий вісник Львівського національного університету ветеринарної медицини та біотехнологій імені С. З. Гжиџького. Серія : Економічні науки. 2017. T. 19. № 76. С. 19-25.

${ }^{3}$ Сайт моніторингу за операціями з криптовалютою. URL: http://hyipstat.top 
2. The threat of national currency. Increased use in the calculation of certain forms of currency strength, and so wide spread use cryptocurrency in Ukraine may weaken the national currency. In recent years it has depreciated significantly against the dollar, so it is important to stabilize the economic situation in our country that the national currency was able to withstand the new competitor.

3. Failure to conduct effective monetary policy, as large portion of money is beyond the control of monetary regulator.

4. Irreversibility of transactions. After payment to cancel the operation is impossible. Therefore, users of a digital currency need thoroughly inspect the entities with which they carry out cash transactions for their reliability assurance and prevention of fraud.

Today in the world there are a large number of cryptocurrency. The most popular are presented in the Table. 1.

According to Table 1 it can be argued that the most popular cryptocurrency is Bitcoin, and the least popular - NEO. In addition, it should be noted that the value of the currency does not meet graduation in popularity. For example Bitcoin exchange is the largest and 6 is $\$ 839.03$, while the rate of Tron $-0.04 \$$, although this type of cryptocurrency heads fifth place in the ranking.

Bitcoin, but the first place among popular with users is also the first cryptocurrency in the world, which was established in 2009 by a programmer (or group of programmers) under the pseudonym Satoshi Nakamoto without a part of the state as an alternative to "classical" currencies based on other than these principles of emissions and circulation to ignore conservative fiat-credit monetary system outside which the ordinary course money cannot be existed ${ }^{4}$. Bitcoin is a distributed peer network in which no single emission center and emission occurs automatically based on a mathematical algorithm. Each member of the network involved in the maintenance of the network. To ensure the anonymity of all transactions in the network uses asymmetric cryptographic methods of encoding encryption using public and private keys. The feature of the technology is Bitcoin block chain. This is a public database of all transactions ever made in Bitcoin system, which is organized in data blocks. Each newly created block contains the hash of the previous amount.

\footnotetext{
${ }^{4}$ Graydon C. What is cryptocurrency? CryptoCoinsNews, 2014. URL: https://www.cryptocoinsnews.com/ cryptocurrency/
} 
Thus creating a continuous chain of interconnected blocks of information that originates from the so-called genesis block (the first block in the system Bitcoin) to the last, found by the system unit. Using this database, each user can see how many Bitcoin belonged to wallet in a particular period of time. Block chain is stored simultaneously in all network users.

Table 1

Rating cryptocurrency 2018

\begin{tabular}{|c|c|c|c|c|}
\hline № & Currency & Course & $\begin{array}{c}\text { Capitalization / } \\
\text { released }\end{array}$ & $\begin{array}{c}\text { Space for } \\
24 \text { hours. }\end{array}$ \\
\hline 1 & Bitcoin (BTC) & $6 \$ 839.03$ & $\begin{array}{c}116050816167 \$ \\
16968900\end{array}$ & $4237770000 \$$ \\
\hline 2 & Tether (USDT) & $\$ 1.00$ & $\begin{array}{c}2284581503 \$ \\
2287140814\end{array}$ & $1226710000 \$$ \\
\hline 3 & Ethereum (ETH) & $\$ 410.56$ & $\begin{array}{c}40538793356 \$ \\
98739279\end{array}$ & $1157230000 \$$ \\
\hline 4 & Verge (XVG) & $\$ 0.09$ & $\begin{array}{c}1302157411 \$ \\
14859467328\end{array}$ & $\$ 478,459,000$ \\
\hline 5 & Tron (TRX) & $\$ 0.04$ & $\begin{array}{c}2423948782 \$ \\
65748111645\end{array}$ & $\$ 305,793,000$ \\
\hline 6 & Bitcoin Cash (BCH) & $\$ 649.92$ & $\begin{array}{c}11091621629 \\
\$ 17066213\end{array}$ & $\$ 221,670,000$ \\
\hline 7 & Litecoin (LTC) & $\$ 114.02$ & $\begin{array}{c}6388034663 \$ \\
56025563\end{array}$ & $\$ 201,057,000$ \\
\hline 8 & Ripple (XRP) & $\$ 0.49$ & $\begin{array}{c}19230242844 \$ \\
39094520623\end{array}$ & $\$ 155,845,000$ \\
\hline 9 & Ontology (ONT) & $\$ 4.50$ & $\begin{array}{c}1085006773 \$ \\
241236451\end{array}$ & $\$ 136,131,000$ \\
\hline 10 & NEO (NEO) & $\$ 52.16$ & $\begin{array}{c}3390335000 \$ \\
65000000\end{array}$ & $\$ 97,304,000$ \\
\hline
\end{tabular}

Source: the authors summarized based on ${ }^{5}$

Trade agreements using bitcoins held in electronic format, and purchase and sale of currency can be done through online exchanges (e.g., BTC-E). With special exchangers in online networks (Web Money) or through a broker (FX Open) cryptocurrency can be exchanged for the

\footnotetext{
${ }^{5}$ Сайт моніторингу за операціями з криптовалютою. URL: http://hyipstat.top
} 
major currencies of the world. Also bitcoins can get by taking payment for the goods and services directly or through the purchase of another owner. The last option is considered the most advantageous because it does not include fees charged in the exchange office.

Another way to get digital currency is Mining. It is that in computers of users who are in different places, planed install special software with the help of which in result of solving mathematical tasks form bitcoins.

Consequently in the context of the rapid development of ITtechnologies, the rapid spread of cryptocurrency in the world is an indisputable phenomenon. Its popularity lies in two features - anonymity and decentralization. There is a theory that in the future cryptocurrency will become the successor to paper money, completely taking over their functions on themselves.

It should be noted that the use of cryptocurrency is a predominantly new phenomenon in the world. Despite the lack of legal definition, cryptocurrency as a form of calculation began to gain popularity in many countries around the world. Interest in digital currencies is also gaining momentum in Ukraine.

This is caused by the crisis of the domestic banking system, the instability of the hryvnia, the changing course of currency and other socioeconomic difficulties that are concentrated on the financial system of Ukraine. In Ukraine, the real popularity of cryptocurrency began in 2014, when enthusiasts created a social organization with the aim of distributing, developing and studying bitcoin and other virtual currencies on the territory of our state - Bitcoin Foundation Ukraine (DFU). Approximately at that time, the first companies and agencies began to appear, including those offering a physical exchange of cryptocurrency for cash, as well as making online cash transactions.

Cryptocurrency in Ukraine can be earned, bought or given. Some online stores and businesses indicate on their websites that they accept cryptocurrency as payment for goods or services. In some countries, employers already pay salaries to their employees in cryptocurrency, usually those who work online - in Ukraine, this practice is only beginning to spread. Today, wages in cryptocurrency among Ukraine are received mostly IT professionals working for foreign companies. Sometimes cryptocurrency can also be obtained free of charge: it's small gift amounts that attract people around the world. To do this, just enter the 
CAPTCHA or view the advertisement and for this, for example, Satoshi (one hundred millionth bitcoin) will be counted. Gifts are possible from great service, for example, for a good post or article, a picture that is in demand by other users ${ }^{6}$

Given the significant growth of interest in virtual currency among residents of Ukraine there is urgent need of legal regulation of cryptocurrency, problem which lies in the fact that the relationship with cryptocurrency cannot be directly applied that or another current legislation. This conflict arose due to the fact that according to the legal norms cryptocurrency cannot be equated neither to means of payment nor to the currency value.

In this regard the National Bank said: "The issue of virtual currency Bitcoin does not have any security and legal obligations for the persons, it is not controlled by the state authorities of either country. So, Bitcoin is money substitutes, which does not provide real value",

So cryptocurrency means the type of digital currency, the account of which is possible using cryptographic techniques ${ }^{8}$.

Chairman of the Commission on Commodities Commerce of the USA (CFTC) Christopher Giancarlo said that cryptocurrency has the future, but competition for hard currency and dollar they do not make ${ }^{1 .}$

\section{The Main Approaches of State Regulation and Accounting for Transactions with Cryptocurrency}

Note that cryptocurrency legal status remains ambiguous and its records are maintained in accordance with the professional judgment of an accountant. Therefore, the Supreme Rada registered just two bills concerning the legal status and treatment of cryptocurrency and intended to create a legislative framework for the use of cryptocurrency.

Draft Law of Ukraine of 10.10.2017 p. № 7183-1 “On stimulating the market of cryptocurrency and their derivatives in Ukraine" 9 defines

\footnotetext{
${ }^{6}$ Гусєва I.І., Петрова Т.О. Тенденції розвитку криптовалют на ринку України. Науковий вісник Міжнародного гуманітарного університету. Сер. Економіка і менеджмент. 2017 . № 24 ч. 1. С. 48-50.

7 Лист Національного банку «Щодо віднесення операцій з віртуальною валютою/криптовалютою «Bitcoin» до операцій 3 торгівлі іноземною валютою, а також наявності підстав для зарахування на поточний рахунок в іноземній валюті фізичної особи іноземної валюти, отриманої від продажу Bitcoin» №29-208/72889 08.12.2014 p. URL: http://zakon3.rada.gov.ua/laws/show/v2889500-14

${ }^{8}$ Багинський О.В. Перспективи використання криптовалюти Вitcoin. Матеріали міжнародної наукової конференції. Міжнародне науково-технічне співробітництво: принциии, механізми, ефективність (Київ 1314 бер. 2014). Київ : НТУУ «КПІ», 2014. С. 10-11.
} 
cryptocurrency as decentralized digital measurement of value that can be expressed in numerical form and function as a medium of exchange, store of value or unit of account, based on mathematical calculations, is the result of a cryptographic protection of accounting. Cryptocurrency for the purpose of regulation is a financial asset. This project provides for the introduction of $2 \%$ tax on compulsory state pension insurance with each ecash transaction operation, resulting in additional revenues to the state budget of Ukraine.

Bill № 7183 "On Circulation cryptocurrency in Ukraine", determined that cryptocurrency is a software code (a set of symbols, numbers and letters) that are the subject of property rights, which may be a means of exchange, information is entered and stored blokchain system as accounting unit blokchain current system in the form of data (code). The draft states that cryptocurrency applies general rules that apply to private ownership and transactions e-cash to the general provisions of barter, in accordance with the laws of Ukraine. The project also provides for distribution of tax legal operations of Mining and Mines (exchange) cryptocurrency, according to the current legislation of Ukraine (that cryptocurrency will be subject to tax).

To date none of the above mentioned legislation has not yet entered into force. However, purchases and sales of cryptocurrency according to legislation regarded as an activity which aims to profit, so actually the business activities subject to taxation ${ }^{11}$.

Considering the sale and purchase cryptocurrency of individual note that according to art. 163.1 $\mathrm{TCU}^{9}$ resident is subject to tax: the total monthly (annual) taxable income; income originating in Ukraine, which ultimately taxed when it charges (payments provision); Foreign income income (profit) derived from sources outside Ukraine. Note that the actual individual in transactions of sale or purchase cryptocurrency is in Ukraine, but all operations are taking place abroad. Confirmation of the transaction outside of Ukraine may be that the most direct trade exchanges on which transactions occur registered outside of Ukraine. An example is the

\footnotetext{
9 Проект закону України «Про стимулювання ринку криптовалют та їх похідних в Україні» №7183-1 від 10.10.2017 p. URL: http://w1.c1.rada.gov.ua/pls/zweb2/webproc4_1?pf3511=62710

10 Проект закону України «Про стимулювання ринку криптовалют та їх похідних в Україні» №7183 - 1 від 10.10.2017 p. URL: http://w1.c1.rada.gov.ua/pls/zweb2/webproc4_1?pf3511=62710

11 Податковий кодекс України: Закон України №2755-VI від 02.12.2010 p. BBP. 2011. URL: http://zakon3.rada.gov.ua/laws/show/2755-17
} 
exchange www.yobit.net. According to the Web resource www.whois.com it is registered in Russia. Actually, place of purchases and sales on the stock exchange of cryptocurrency is the country of registration of the exchange. So purchases and sales of cryptocurrency should be regarded as "foreign income" derived from sources outside Ukraine, because the trade deal with the sale process and profit take place beyond Ukraine.

Also buying and selling cryptocurrency are not operations "investment assets", therefore cannot be taxed at a rate of $5 \%$ as the position p. 170.2 $\mathrm{TCU}^{9}$ contains an exhaustive list of concepts referred to as "investment assets" and "investment income". Information about assets like cryptocurrency it is not reflected.

Interesting is the fact that the transaction of the acquisition cryptocurrency is not taxable as a result of this operation is not received profit. However, if cryptocurrency was sold at a higher price than acquired, the positive difference on its legal merits will be considered passive income as an individual buyer does not directly affect the cost of growth factors cryptocurrency. But the current situation p. 170.2 TCU does not recognize cryptocurrency "investment income" and "investment assets", and therefore profit from such sale cannot be taxed under the provisions of paragraph 170.2 TCU at a reduced rate of $5 \%$.

This income should be interpreted as "any income received by residents" and "other income from any activities outside the customs territory of Ukraine" according to the claim p. 14.1.55 TCU, so it is liable to tax on a common basis at the rate of $18 \%$ which provides p. 167.1 $\mathrm{TCU}^{12}$.

The obligation to pay accrued tax arises on the day of profit, the day transfer of funds from the sale / exchange cryptocurrency for money. But it is paid to 01 August next year.

It should also be emphasized that the tax will be subject only to income derived, that is to say cryptocurrency which was exchanged for cash and transferred to a bank account / card of individual. Exchanges cryptocurrency one to another will not be taxed given the fact that the exchange cryptocurrency one to another is not income. When exchanging cryptocurrency should pay attention to the cost of the first investment, i.e. the amount for which you purchased the first cryptocurrency as well as the

12 Проект закону України «Про обіг криптовалюти» №7183 від 06.10.2017 p. URL: http://w1.c1.rada.gov.ua/pls/zweb2/webproc4_1?pf3511=62684 
amount for which it was exchanged (sold) at the latest cryptocurrency currency. The positive difference resulting from the transactions will be subject to tax at the rate of $18 \%$.

Considering the operations of non-residents in Ukraine on sale and purchase cryptocurrency and taking into account the provisions of paragraph 163.2 TCU, we can say that the income of non-residents from transactions with sale cryptocurrency taxed not even provided the resident is physically located in Ukraine, since purchases sale of cryptocurrency occur outside Ukraine, namely at the exchange. Non-resident has to pay taxes in the country in which he is. An exception will be transactions with non-residents on sale and purchase cryptocurrency undertaken at Ukrainian exchanges. These operations will apply the general rule as to the taxation of residents.

The world's leading standards bodies have also began to consider and investigate this perspective. Thus, the Council for Standardization US Financial Accounting, outlined the range of issues that need clarification, such as aspects of recognition, measurement and calculation of virtual currency ${ }^{13}$.

Despite centuries of development is still in the theory and practice of monetary relations found many contradictions and unexplored areas.

One of these areas is an alternative currency, which includes the emission and use of a calculation tool extra money, namely cryptocurrency.

Because of active development of relations cryptocurrency important need arises implementation of legislative regulation. And first of all, each country should provide legal status of cryptocurrency. In various states methods for solving this problem differ (tab. 2).

However, despite revealing a positive attitude to cryptocurrency in the most developed countries, some countries virtual currency is considerable distrust and there cryptocurrency use is prohibited. These include Bangladesh, Bolivia, Ecuador, Vietnam, Iceland, China.

Thus, the international practice of using cryptocurrency indicates that states have different attitudes to its introduction into circulation. The reason is mainly the novelty of the instrument and the lack of a single definition of the "cryptocurrency" that discloses its economic substance.

\footnotetext{
${ }^{13}$ Доповідь радників для Голови Ради зі стандартів фінансового обліку США_квітень 2014 p. URL: http://www.fasb.org/jsp/FASB/Document_C/Documentpage\&cid=1176164360924
} 


\section{The experience of foreign countries to state regulation and use cryptocurrency}

\begin{tabular}{|c|c|}
\hline Country & Characteristic \\
\hline United States & $\begin{array}{l}\text { One of the most comfortable in the world of cryptocurrency for } \\
\text { doing business. It is incorporated large hedge funds, exchanges and } \\
\text { other companies associated with cryptocurrency. For many goods } \\
\text { and services can pay not only fiat or electronic money, but also } \\
\text { digital. Also common in the US ATMs (ATM), enabling the } \\
\text { exchange cryptocurrency. Among the regulators is no common } \\
\text { position on the legal status cryptocurrency. Digital currency is seen } \\
\text { both as money (their equivalent), property and commodities. At the } \\
\text { federal level, some cryptocurrency companies (e.g., Exchange) } \\
\text { should be registered as operators of the web transfer funds to } \\
\text { combat financial crime, and at the state level activities of such } \\
\text { companies to be licensed. Real cryptocurrency taxed. For example, } \\
\text { wages paid in Bitcoin, is the subject of the federal income tax and } \\
\text { payroll tax. }\end{array}$ \\
\hline Canada & $\begin{array}{l}\text { Ranked second in the world after the United States for the number } \\
\text { of set-bitcoin ATMs. In order to better understanding the } \\
\text { technology Blokchain state develops digital version of the } \\
\text { Canadian dollar based on it. This activity of cryptocurrency } \\
\text { exchanges was settled back in } 2014 \text { when the bill was approved, } \\
\text { under which such exchanges should be registered at the Canadian } \\
\text { Center for Analysis and reporting of financial transactions and } \\
\text { obliged to comply with legislation on counteraction to legalization } \\
\text { (laundering). In Canada, payment for goods and services using } \\
\text { digital money is taxable as barter. In addition, during the sale } \\
\text { cryptocurrency tax on income (Income Tax), income tax } \\
\text { (Corporation Income Tax) or capital gains tax. }\end{array}$ \\
\hline Australia & $\begin{array}{l}\text { Demonstrates intention to become one of the most progressive } \\
\text { jurisdictions. Digital currency is not regarded as a financial } \\
\text { product, so cryptocurrency activities are not subject to licensing } \\
\text { (with the exception of activities related to fiat money or other } \\
\text { financial products). Australia has actively developed legislation on } \\
\text { counteraction to legalization (laundering) of proceeds from crime } \\
\text { and terrorist financing, which would imply the ability to use digital } \\
\text { currencies to commit these crimes. Real cryptocurrency taxed } \\
\text { according to standard rules of taxation, i.e. income tax and profit } \\
\text { tax. However, when used as an investment cryptocurrency no need } \\
\text { to tax capital gains. In addition, in December } 2016 \text { the Code of } \\
\text { behavior became real for members of industry digital currency. }\end{array}$ \\
\hline
\end{tabular}


Continuation of Table 2

\begin{tabular}{|c|c|}
\hline $\begin{array}{l}\text { United } \\
\text { Kingdom }\end{array}$ & $\begin{array}{l}\text { There cryptocurrency integration leader and one of the most } \\
\text { convenient and the most favorable jurisdictions for cryptocurrency } \\
\text { doing business. In addition, the state provides support to entities } \\
\text { associated with the digital currency. However, the final position of } \\
\text { the government on regulation of activities associated with digital } \\
\text { money has not yet been produced. In } 2014 \text { the United Kingdom } \\
\text { government body reaffirmed that Bitcoin - it is not currency, not } \\
\text { money, because cryptocurrency no way regulated financial } \\
\text { legislation in United Kingdom. Until now, digital currency in the } \\
\text { United Kingdom believe the unique combination of digits obtained } \\
\text { from the complex mathematical calculations and algorithms }\end{array}$ \\
\hline Japan & $\begin{array}{l}\text { Since April } 2017 \text { passed a law under which Bitcoin and other } \\
\text { cryptocurrency equal in status to fiat money and become legal } \\
\text { tender. Japan became the first country in the world to do so. One of } \\
\text { the shocks to provide cryptocurrency status of legal tender collapse } \\
\text { began trading on one of the largest Bitcoin exchanges-MTGox and } \\
\text { its bankruptcy in } 2014 \text {, so that its customers have suffered huge } \\
\text { losses and cryptocurrency rate fell heavily. It is to prevent such } \\
\text { situations and protect the rights of consumers, Japan performs } \\
\text { legislative regulation of the issue. }\end{array}$ \\
\hline Austria & $\begin{array}{l}\text { In Vienna, opened the world's first Bitcoin Bank. The bank has to } \\
\text { make buying and selling Bitcoin easier and safer. The bank } \\
\text { established a special ATMs that allow Bitcoin exchange to the euro } \\
\text { and vice versa. Bank customers can also get them interested in } \\
\text { information on virtual currency. The project was very successful, } \\
\text { and after Bitcoin ATMs began to appear in other places. }\end{array}$ \\
\hline Germany & $\begin{array}{l}\text { German Finance Ministry has officially recognized the Bitcoin } \\
\text { instrument and made appropriate changes in the Banking Code. In } \\
\text { particular, Germany is set bitcoin legal status as private money and } \\
\text { clearing in this cryptocurrency on the territory of the state. }\end{array}$ \\
\hline Netherlands & $\begin{array}{l}\text { Most daring attitude to cryptocurrency demonstrated the } \\
\text { Netherlands, where it was created "city Bitcoin" and determined } \\
\text { the highest concentration of companies providing goods and } \\
\text { services for Bitcoin. You cannot just pay for legal services, but also } \\
\text { a haircut, buy a hamburger or a new suit, send an email to fix } \\
\text { appliances or rent a hotel room. }\end{array}$ \\
\hline Sweden & $\begin{array}{l}\text { Another country that has a favorable attitude to cryptocurrency is } \\
\text { Sweden. Cryptocurrency are widely used in the form of payment. } \\
\text { The population of Sweden is almost completely abandoned cash. } \\
\text { The proportion of cash payments in trade declined sharply from } \\
40 \% \text { in } 2010 \text { to } 15 \% \text { in } 2016 \text {. In addition, the question of } \\
\text { establishing a national cryptocurrency that have comprised the } \\
\text { advantages of public money and virtual independence. }\end{array}$ \\
\hline
\end{tabular}


Ending of Table 2

\begin{tabular}{|l|l|}
\hline EU countries & $\begin{array}{l}\text { Considering the legislative activity of the EU, it should be noted } \\
\text { that none of them have adopted specific rules regulating } \\
\text { cryptocurrency activities. However, in } 2016 \text { the European } \\
\text { Commission proposed a regulation for an extra cryptocurrency } \\
\text { exchanges and companies providing cryptocurrency wallet users. } \\
\text { Also, EU tax cryptocurrency and operations with it carried out in } \\
\text { accordance with national laws of the Member States. The exception } \\
\text { is the value added tax, since November } 2015 \text { the Court (European } \\
\text { Court of Justice) ruled under which transactions of sales and } \\
\text { purchase of Bitcoin for the traditional fiat money is not taxed. }\end{array}$
\end{tabular}

Source: the authors systematically through ${ }^{14,15}$

As a result of thorough research on adherence cryptocurrency standard classifications, foreign researchers reached their conclusions:

1) Bitcoins not be considered cash, as most companies do not accept them because bitcoins classification as unrealistic costs;

2) Bitcoins not be classified as cash equivalents because they are not highly liquid, not easily convertible. Bitcoins impossible to put on a bank deposit or cash from ATMs, due to the extremely high rate volatility, and therefore not subject to the criterion insignificant risk of changes in value;

3) Bitcoins although no material form, it cannot be regarded as an intangible asset. Because of the intangible assets not attributable financial instruments, but bitcoins, which is not cash, serves as a means of financial exchange, it is actually a financial instrument ${ }^{16}$.

Thus, according to researchers, is noteworthy in modern conditions the most appropriate classification group for cryptocurrency is investments.

Taking into account the change in value of investment in accounting it's necessary to display their revaluation on each balance sheet date, which

14 Гончаренко О.С. Особливості функціонування криптовалют на 32 світових ринках. Миколаївський національний університет імені В.О. Сухомлинського. 2015. Випуск 5. URL: http://globalnational.in.ua/archive/5-2015/168.pdf

${ }^{15}$ Ситник І.П., Пюро Б.І. Аналіз сучасного стану та перспектив розвитку криптовалюти bitcoin в умовах розвитку інформаційної економіки. Вісник Одеського національного університету. Сер. Економіка. 2017. № 22. Вип. 1. С. 157-160.

16 Raiborn, C., Sivitanides, M. Accounting Issues Related to Bitcoins. Journal of Corporate Accounting\&Finance. 2015. URL: https://onlinelibrary.wiley.com/doi/10.1002/jcaf.22016/epdf?r3_referer= wol\&tracking_action=preview_click\&show_checkout=1\&purchase_referrer=onlinelibrary.wiley.com\& purchase_ site_license= LICENSE_DENIED. 
directly affect the item of other income and expenses (p. $8 \mathrm{P}(\mathrm{S}) \mathrm{BO} 12^{17}$, p. $\left.32 \mathrm{P}(\mathrm{S}) \mathrm{BO} 13^{18}\right)$.

Companies that keep records of IFRS, the revaluation surplus are credited depending on the classification of financial instruments - to the financial results or to capital.

Taking into account the current business realities that contribute to that cryptocurrency gaining new segments of world trade, is used to pay for online goods and services, it should be noted that currently in Ukraine there are no regulatory instructions regarding accounting operations cryptocurrency.

According to the above legislative initiatives and given the need to regulate transactions associated with your directions formulated cryptocurrency software that can affect the value of business entities:

- primary current account of certain types and quantities cryptocurrency serving as a means of payment or exchange for traditional now for free exchange rate is formed on open Internet sites;

- analytical accounting cryptocurrency according to the species listed in the table. 1, which will enhance controls these financial instruments;

- accounts of spending for the organization and holding exchanges exchangers, open Internet sites that perform the function of exchange; for training personnel which will carry out operations with cryptocurrency and acquisition related software etc.;

- accounting taxation connected with the use cryptocurrency, recording the requirements of current legislation.

\section{CONCLUSIONS}

The results of the research on the regulation of company operations associated with the use cryptocurrency, made the following conclusions:

- cryptocurrency use is mostly a new phenomenon in the world. Despite the lack of legal definition, a form of calculation cryptocurrency started to gain significant popularity in many countries. Revealed that the rapid development of IT- technologies cryptocurrency rapid expansion in the world is indisputable phenomenon. Its popularity lies in two features -

\footnotetext{
17 Положення (стандарт) бухгалтерського обліку 12 «Фінансові інвестиції» : Наказ Міністерства фінансів України від 26.04.2000 № 91. URL: http://zakon2.rada.gov.ua/laws/ show/z0284-00

${ }^{18}$ Положення (стандарт) бухгалтерського обліку 13 «Фінансові інструменти» : Наказ Міністерства фінансів України від 30.11.2001 № 559. URL: http://zakon5.rada.gov.ua/laws/ show/z1050-01
} 
anonymity and decentralization. In the future cryptocurrency may become the successor of paper money, fully adopting their functions themselves;

- analysis of the essence cryptocurrency allowed to provide such the following definition: cryptocurrency is a decentralized digital measurement value that can be expressed in numerical form, produced by Mining and functions as a means of payment, exchange, store of value or unit of account and a cryptographic protection;

- analysis of foreign experience in government regulation, use, accounting and taxation of cryptocurrency allowed to state that cryptocurrency, though is not considered cash serves as a means of financial exchange, is actually a financial instrument. Therefore, in the present conditions the most appropriate classification group for cryptocurrency is investments;

- for the purposes of cost management business conditions of business transactions related to cryptocurrency need to provide:

- primary current account number, types cryptocurrency now used to facilitate the control and efficient use of these financial instruments;

- cryptocurrency of analytical accounting entity that provides the ability to control its movement, including the use of different types of cryptocurrency for individual enterprises;

- accounting reflection of function of function cryptocurrency exchange, services of brokers, personnel training and others that determine the value of spending related to activity of an enterprise to implement operations with cryptocurrency;

- determining the order of taxation of Mining, exchange cryptocurrency to facilitate additional revenues to the state budget of Ukraine and establishing liability company for violation of applicable regulatory requirements regarding the use cryptocurrency.

Prospects for further research is the introduction of special software which will record cryptocurrency possible in accordance with national and international accounting standards.

\section{SUMMARY}

The purpose of the study is to analyse the legal regulation of the functioning of cryptocurrency in Ukraine, as well as the approaches to accounting for operations related to it, taking into account the practice of foreign states. 
The author pays attention at that despite centuries of development, as before, in the theory and practice of monetary relations, there are many contradictions and unexamined aspects. One of such aspect is alternative money circulation, which involves the use as a calculating tool of cryptocurrency the accounting of which is based on asymmetric encryption and the application of various cryptographic methods of protection. Up to date there are a lot of cryptocurrency in the world. The most popular among them is Bitcoin.

The publication examines the peculiarities of displaying information on operations of an enterprise, related to cryptocurrency and due to innovative approaches to doing business. The author's definition of cryptocurrency is proposed, taking into account its economic essence. The main directions of accounting of operations related to cryptocurrency are formulated, which will allow to improve the process of managing the cost of business in the conditions of such operations. The peculiarities of taxation of operations with cryptocurrency are determined, taking into account the requirements of the current legislation.

\section{REFERENCES}

1. Obozrevatel / Ринки та компанії, 16 травня 2019 р. URL: https://www.obozrevatel.com/ukr/economics/economy/kurs-dolara-vpavna-95-analitiki-ozvuchili-nespodivanij-prognoz.htm

2. Васильчак С.В., Куницька-Іляш М.В., Дубина М.П. Використання криптовалют в сучасних економічних системах України: перспективи та ризики. Науковий вісник Львівського національного університету ветеринарної медицини та біотехнологій імені С. 3. Гжицького. Серія : Економічні науки. 2017. Т. 19. № 76. С. 19-25.

3. Сайт моніторингу за операціями 3 криптовалютою. URL: http://hyipstat.top

4. Graydon C. What is cryptocurrency? CryptoCoinsNews, 2014. URL: https: // www.cryptocoinsnews.com/cryptocurrency/

5. Гусєва I.I., Петрова Т.О. Тенденції розвитку криптовалют на ринку України. Науковий вісник Міжнародного гуманітарного університету. Сер. Економіка і менеджмент. 2017. № 24 ч. 1. С. 48-50.

6. Лист Національного банку «Щодо віднесення операцій 3 віртуальною валютою/криптовалютою "Bitcoin” до операцій з торгівлі іноземною валютою, а також наявності підстав для зарахування на 
поточний рахунок в іноземній валюті фізичної особи іноземної валюти, отриманої від продажу Bitcoin” № 29-208/72889 08.12.2014 p. URL: http://zakon3.rada.gov.ua/laws/show/v2889500-14

7. Багинський О.В. Перспективи використання криптовалюти Bitcoin. Матеріали міжнародної наукової конференції. Міжнародне науково-технічне співробітництво: принципи, механізми, ефективність (Київ 13-14 бер. 2014). Київ : НТУУ «КПІ», 2014. C. $10-11$.

8. Проект закону України «Про стимулювання ринку криптовалют та їх похідних в Україні» № 7183 - 1 від 10.10.2017 р. URL: http://w1.c1.rada.gov.ua/pls/zweb2/webproc4_1?pf3511=62710

9. Проект закону України «Про обіг криптовалюти» № 7183 від 06.10.2017 p. URL: http://w1.c1.rada.gov.ua/pls/zweb2/webproc4_1?pf35 $11=62684$

10. Податковий кодекс України: Закон України № 2755-VI від 02.12.2010 p. BBP. 2011. URL: http://zakon3.rada.gov.ua/laws/show/ 2755-17

11. Доповідь радників для Голови Ради зі стандартів фінансового обліку США_квітень 2014 p. URL: http://www.fasb.org/jsp/FASB/ Document_C/Documentpage\&cid $=1176164360924$

12. Гончаренко О.С. Особливості функціонування криптовалют на 32 світових ринках. Миколаӥвський національний університет імені B.О. Сухомлинського, 2015. Випуск 5. URL: http://globalnational.in.ua/ archive/5-2015/168.pdf

13. Ситник І.П., Пюро Б.І. Аналіз сучасного стану та перспектив розвитку криптовалюти bitcoin в умовах розвитку інформаційної економіки. Вісник Одеського національного університету. Сер. Економіка. 2017. № 22. Вип. 1. С. 157-160.

14. Raiborn, C., Sivitanides, M. Accounting Issues Related to Bitcoins. Journal of Corporate Accounting\&Finance. 2015. URL: https://onlinelibrary.wiley.com/doi/10.1002/jcaf.22016/epdf?r3_referer=w ol\&tracking_action=preview_click\&show_checkout=1\&purchase_referrer $=$ onlinelibrary.wiley.com\&purchase_site_license=LICENSE_DENIED

15. Положення (стандарт) бухгалтерського обліку 12 «Фінансові інвестиції» : Наказ Міністерства фінансів України від 26.04.2000 № 91. URL: http://zakon2.rada.gov.ua/laws/show/z0284-00 
16. Положення (стандарт) бухгалтерського обліку 13 «Фінансові інструменти» : Наказ Міністерства фінансів України від 30.11.2001 № 559. URL: http://zakon5.rada.gov.ua/laws/show/z1050-01

\section{Information about the author:}

Ovsyuk N. V.

Doctor of Economic Sciences, Associate Professor at the Department of Economics, Entrepreneurship and the Natural Sciences, V. I. Vernadsky Taurida National University 33, John McCain str., Kyiv, 02000, Ukraine 